\title{
Gene Therapies for Neovascular Age-Related Macular Degeneration
}

\author{
Peter Pechan, Samuel Wadsworth, and Abraham Scaria \\ Gene Therapy, Sanofi-Genzyme R\&D Center, Framingham, Massachusetts 01701 \\ Correspondence: abraham.scaria@genzyme.com
}

Pathological neovascularization is a key component of the neovascular form (also known as the wet form) of age-related macular degeneration (AMD) and proliferative diabetic retinopathy. Several preclinical studies have shown that antiangiogenesis strategies are effective for treating neovascular AMD in animal models. Vascular endothelial growth factor (VEGF) is one of the main inducers of ocular neovascularization, and several clinical trials have shown the benefits of neutralizing VEGF in patients with neovascular AMD or diabetic macular edema. In this review, we summarize several preclinical and early-stage clinical trials with intraocular gene therapies, which have the potential to reduce or eliminate the repeated intravitreal injections that are currently required for the treatment of neovascular AMD.

\begin{abstract}
A ge-related macular degeneration (AMD) is the leading cause of central vision loss in individuals 65 years of age and older. Neovascular AMD, the most severe form of AMD, is characterized by subretinal or choroidal neovascularization $(\mathrm{CNV})$. It often leads to permanent vision loss and the inability to read, write, recognize faces, or drive (Klein et al. 1992). Conventional therapies approved by the United States Food and Drug Association (FDA) were laser thermal photocoagulation and photodynamic therapy with intravenous injection of verteporfin (Visudyne, Valeant Pharmaceuticals) (Miller et al. 1999). Visudyne was the first drug therapy approved for treatment of wet AMD and is efficacious in patients who have predominantly classic lesions of CNV. The first anti-VEGF drug, pegaptanib sodium (Macugen, Eyetech Inc. and Pfizer) (Gragoudas et al. 2004), was approved by the FDA in December
\end{abstract}

2004 for all angiographic subtypes of neovascular AMD. Although the previous treatments can slow the progression of vision loss, only a small percentage of treated patients experienced any improvement in visual acuity. Ranibizumab (Lucentis, Genentech), introduced earlier (Brown et al. 2006; Rosenfeld et al. 2006) and aflibercept (Eylea, also known as VEGF TrapEye; Regeneron) (Heier et al. 2012) were approved by the FDA in June 2006 and in November 2011, respectively, for the treatment of all subtypes of neovascular AMD. An antiplateletderived growth factor (anti-PDGF) aptamer agent, Fovista (Ophthotech), is currently in clinical trials and is being tested in combination with ranibizumab. The combination is showing potential to be an additional treatment alternative for wet AMD (Boyer et al. 2009).

Although these treatments maintain vision (and in some cases improve vision), they require

Editors: Eric A. Pierce, Richard H. Masland, and Joan W. Miller

Additional Perspectives on Retinal Disorders: Genetic Approaches to Diagnosis and Treatment available at

www.perspectivesinmedicine.org

Copyright (C) 2015 Cold Spring Harbor Laboratory Press; all rights reserved; doi: 10.1101/cshperspect.a017335

Cite this article as Cold Spring Harb Perspect Med 2015;5:a017335 
P. Pechan et al.

repeated treatments to remain effective. Hence, they still require years of frequent intravitreal injections, which can increase the potential risk of endophthalmitis and are inconvenient for patients, their families, and the treating physicians. An attractive alternate approach involves using a single intraocular injection of a gene therapy vector that would continuously express an antiangiogenic protein to block pathological neovascularization in AMD. Here we summarize the rationale and progress of preclinical and clinical trials using gene delivery strategies for the treatment of neovascular AMD. The gene delivery vectors used in these studies include adenoviral vectors (Ad), helper-dependent Ad vectors, adeno-associated viral vectors (AAV), and lentiviral vectors.

\section{MOLECULES DELIVERED USING GENE THERAPY}

\section{VEGF Inhibitors}

Formation of choroidal neovessels that penetrate the subretinal space, because of overproduction of growth factors such as vascular endothelial growth factor (VEGF), is the main cause of vision loss in neovascular AMD. VEGF also plays a significant role in the leakage of new intraretinal blood vessels in proliferative diabetic retinopathy (Connolly et al. 1989; Ferrara and Henzel 1989; Aiello et al. 1995; Ferrara et al. 1998). Knowing the role of VEGF in the formation of these neovessels is the determining factor in the development of anti-VEGF therapies. It has been shown that VEGF is necessary for development and maintenance of pathological neovascularization, and blockade of VEGF receptor signaling via VEGF receptor 1 (VEGFR1, Flt) or VEGFR-2 (Flk, KDR) is sufficient to inhibit neovascularization (Aiello et al. 1995; Ozaki et al. 2000). The four main biological effects of VEGF, as determined by Ferrara and Gerber (2001), are increase in vascular permeability, growth and proliferation of vascular endothelial cells, migration of vascular endothelial cells, and survival of immature endothelial cells by preventing apoptosis. The role of VEGF in inducing retinal neovascularization and vascu- lar leakage has been confirmed in several animal models using ocular gene delivery of VEGF (Yu et al. 1999; Rakoczy et al. 2003; Lebherz et al. 2005; Julien et al. 2008). Since the original study in rhesus monkeys (Ryan 1979), laser rupture of Bruch's membrane has become a common technique to induce CNV in different animal species. Increased expression of VEGF has been shown in laser-induced CNV in rats (Yi et al. 1997), and the blockade of VEGF receptor kinase activity (using small molecule inhibitors) has been shown to cause almost complete inhibition of laser-induced CNV in mice (Kwak et al. 2000). Blocking VEGF with antibodies or soluble VEGF receptors and inhibition of VEGF receptor tyrosine kinase activity are strategies that have shown promising preclinical and clinical results in the suppression of retinal neovascularization. Over the years, several potent VEGF inhibitor proteins have been tested in preclinical models. Intravitreal injections of VEGF-neutralizing chimeric proteins, consisting of the extracellular domain of either human Flt or mouse Flk receptors and an immunoglobulin IgG Fc region, suppressed retinal neovascularization in a murine model of ischemic retinopathy (Aiello et al. 1995). Ranibizumab (previously known as rhuFabV2), a humanized anti-VEGF monoclonal antibody fragment, has been shown to prevent laser-induced CNV in an experimental monkey model (Krzystolik et al. 2002). It has been shown that an anti-murineVEGF antibody blocked neovascularizaton in a murine laser CNV model (Campa et al. 2008). Intravitreal injection of VEGF-Trap, a recombinant fusion protein that contains the domain 2 of Flt- 1 and domain 3 of KDR fused to the Fc portion of human IgG1 (Holash et al. 2002), suppressed laser-induced $\mathrm{CNV}$ in a mouse model, and subcutaneous injection of VEGFTrap also significantly inhibited subretinal neovascularization in a VEGF-overexpressing transgenic mouse model (Saishin et al. 2003). The success in preclinical models resulted in introduction of anti-VEGF protein therapy into clinical trials. Ranibizumab (Presta et al. 1997) improved vision in almost half of all treated patients with neovascular AMD (Brown et al. 2006; Rosenfeld et al. 2006), and aflibercept yielded 
similar benefits in patients with neovascular AMD (Heier et al. 2012). Both drugs stabilized existing vision in $>90 \%$ of patients; however, they require frequent intravitreal injections (sometimes for years) by a retinal specialist.

An alternative approach, such as intraocular gene delivery of VEGF antagonists, would remove the need for frequent intravitreal injections and could provide other advantages over the current treatments. VEGF antagonists currently being investigated in this gene delivery approach are variations of the soluble VEGF receptor Flt-1 (Shibuya et al. 1990). These include the secreted form of the VEGF receptor flt-1 (Flt-1 domains 1-6) (Kendall and Thomas 1993; Lai et al. 2002), the entire flt-1 ectodomain (Flt-1 domains 1-7) fused to the Fc portion of human IgG (Aiello et al. 1995; Honda et al. 2000), or sFLT01 (Flt-1 domain 2 fused to the Fc portion of human IgG via a 9-glycine linker) (Pechan et al. 2009).

One of the earliest studies showing inhibition of ocular neovascularization by gene delivery of a VEGF antagonist was described by Honda et al. (2000). An Ad vector expressing flt-1 (domains 1-7) fused to IgG-Fc (flt-ExR) was shown to significantly inhibit subretinal neovascularization when the Ad vector was injected into the femoral muscle in rats (Honda et al. 2000). Several other groups used a naturally occurring soluble decoy Flt-1 receptor (sFlt1), which is an alternatively spliced form of Flt-1 consisting of the first six extracellular Ig-like domains followed by a unique carboxy-terminal extension of 31 amino acids (Kendall and Thomas 1993). Subretinal delivery of AAV-sFlt1 under control of the cytomegalovirus (CMV) promoter was shown to suppress laser-induced CNV (Lai et al. 2002). In the mouse oxygeninduced retinopathy model, intravitreal gene delivery of the secreted form of flt-1 using Ad and $\mathrm{AAV}$ vectors inhibited experimental retinal neovascularization by $\sim 50 \%$ (Bainbridge et al. 2002). Recombinant replication-deficient adenovirus type 5 (Ad5) vectors used in these studies (Ad5.sflt) are E1a- and partially E1b- and E3- Ad5 vectors that express the secreted form of flt-1. The Ad5.sflt almost completely inhibited retinal neovascularization in a rat model of oxygen-induced retinopathy without affecting preexisting retinal vessels (Rota et al. 2004). In nonhuman primate studies, subretinal injection of AAV-sFlt-1 encoding the secreted form of flt-1 resulted in long-term $(8 \mathrm{mo})$ expression of sFlt- 1 and prevented the development of laser photocoagulation-induced $\mathrm{CNV}$ in all treated monkey eyes, with regression of neovascular vessels observed in $85 \%$ of the treated eyes (Lai et al. 2005). Treatment with sFlt-1 did not change the retinal morphology, and the majority of the treated eyes (75\%) retained high numbers of functional photoreceptors as measured by electroretinography (Lai et al. 2005).

In another long-term safety and efficacy study using nonhuman primates, subretinal injection of AAV2.sFlt-1, encoding the secreted form of flt-1, prevented the development of laser photocoagulation-induced CNV in all treated monkey eyes and yielded no evidence of damage to the eyes, no cell-mediated immunity or anterior chamber flare, and normal fundus and electroretinographic responses. Immunological analysis showed that gene therapy involving subretinal injection of AAV2.sFlt-1 did not elicit cell-mediated immunity. Biodistribution analysis showed that AAV2.sFlt-1 could be detected only in the eye and not in the other organs tested (Lai et al. 2012). A clinical trial (phase I/II) with subretinal injection of AAV2 vector expressing the secreted form of flt-1, sponsored by the Lions Eye Institute and Avalanche Biotechnologies, Inc., is currently ongoing in Perth, Western Australia (registration no. NCT01494805). The patients are being randomized to receive a low dose $\left(1 \times 10^{10}\right.$ vector genomes) or high dose $\left(1 \times 10^{11}\right.$ vector genomes) of a single subretinal injection of AAV2.sFlt-1 and will be tested to examine the baseline safety and efficacy.

Our group at Genzyme has generated a novel chimeric VEGF-binding molecule, sFLT01, containing only the second domain of Flt-1 fused to a human IgG1 Fc through a polyglycine linker, 9Gly (Pechan et al. 2009). We have shown that AAV2-mediated intravitreal gene delivery of sFLT01 efficiently inhibits angiogenesis in the mouse oxygen-induced retinopathy model (Pechan et al. 2009). Preclinical efficacy studies 
P. Pechan et al.

of intravitreally administered AAV2-sFLT01 were conducted in both $\mathrm{C} 57 \mathrm{BL} / 6$ mouse and cynomolgus monkey models of laser-induced CNV (Lukason et al. 2011). In the mouse model, the eyes treated with AAV2-sFLT01 showed a very significant reduction in the number of burns with CNV. In cynomolgus monkeys, AAV2-sFLT01 was able to effectively inhibit laser-induced CNV in a dose-dependent manner. Two studies, with a lower dose $\left(2 \times 10^{8}\right.$ or $2 \times 10^{9}$ vector genomes) and a higher dose $\left(2 \times 10^{10}\right.$ vector genomes $)$ of AAV2-sFLT01 were conducted. With the lower dose, none of the sFLT01 treatment eyes showed a statistically significant reduction in leaking CNV lesions compared with the AAV2-Null control eyes. With the higher dose, all AAV2-sFLT01 treated eyes showed a significant reduction in the amount of CNV leakage compared with the naive contralateral control eyes with only $7 \%$ of the AAV2-sFLT01-treated burns showing leakage compared with $56 \%$ in the control eyes (Lukason et al. 2011).

Following intravitreal injection, it was also shown that AAV2-sFLT01 is well tolerated, localized in the eye, and capable of long-term expression in nonhuman primates (MacLachlan et al. 2011). Cynomolgus monkeys given an intravitreal injection of a low dose $\left(2.4 \times 10^{9}\right.$ vector genomes $)$ or high dose $\left(2.4 \times 10^{10}\right.$ vector genomes) of AAV2.sFLT01 showed no electroretinographic or fluorescein angiographic abnormalities for up to $12 \mathrm{mo}$, the longest time point evaluated. Mild to moderate vitreous inflammation that was transient and resolved spontaneously without any drug treatment was seen in the high-dose group, but not the low-dose group. Histopathological examinations of eyes from the low-dose group were normal and those from the high-dose group showed only occasional inflammatory cells in the trabecular meshwork, vitreous, and/or retina. Aqueous levels of sFLT01 measured in these monkey studies ranged from $\sim 10$ to $400 \mathrm{ng} / \mathrm{mL}$ at $1 \mathrm{mo}$. The expression levels were dose-dependent and decreased slightly but were still in the same general range at 12 mo. Vitreous levels of sFLT01 (when measured) were significantly higher than sFLT01 levels in the aqueous. An additional biodis- tribution study, performed in both SpragueDawley rats and cynomolgus monkeys, found only trace amounts of AAV2 vector transiently outside the injected eye (MacLachlan et al. 2011).

These encouraging preclinical efficacy and safety data have led to a Phase I dose-escalating trial testing four doses of AAV2-sFLT01 $(2 \times$ $10^{8}, 2 \times 10^{9}, 6 \times 10^{9}$, and $2 \times 10^{10}$ vector genomes) in patients with advanced neovascular AMD (registration no. NCT01024998; see http://clinicaltrials.gov/). The trial uses a single intravitreal injection with a fixed $100 \mu \mathrm{L}$ volume of the AAV2-sFLT01 vector. Three patients were enrolled in each of the four cohorts to identify the maximal tolerated dose. Additional cohorts of patients are being treated with this maximal dose. Aqueous levels of sFLT01 are being measured in this trial and will provide useful information regarding the level and duration of transgene protein expression as well as safety and biological activity of sFLT01 as measured by optical coherence tomography of the retina. The study is being conducted at multiple medical centers in the United States.

Gene delivery of sFLT01 was studied by another group at the National Eye Institute in Ccl2/Cx3cr1-deficient mice, another model of AMD (Tuo et al. 2012). Previously, it was reported that $\mathrm{Ccl} 2 / \mathrm{Cx} 3 \mathrm{cr} 1$-deficient mice developed a broad spectrum of AMD-like pathology with early onset and high penetrance (Tuo et al. 2007). Subretinally injected AAV5.sFLT01 vector stabilized or arrested the progression of retinal lesions in $C c l 2 / C \times 3 c r 1$-deficient mice. Subretinal injection of AAV5-based vectors typically leads to significant gene expression in photoreceptors and retinal pigment epithelium. The changes in VEGF, ERK phosphorylation, and iNOS in the retinal tissues suggested the involvement of reactive nitrogen species in the retinal lesions. The findings indicate the potentially beneficial effects associated with sFLT01 gene therapy for retinal disease and possibly AMD, given the role of oxidative stress (Tuo et al. 2012).

There have been some reports that longterm systemic inhibition of VEGF in mice can be deleterious to the photoreceptors, retinal pigment epithelium, and choroid (Saint-Geniez 
et al. 2008, 2009). However, one report using double-transgenic mice with doxycycline-inducible expression of the soluble, secreted, fullsize extracellular domain of VEGF receptor1/sFlt-1 coupled to an IgG1 Fc fragment (sVEGFR1Fc,) indicated that constant blockade of VEGF for up to 7 mo has no identifiable deleterious effects on the retina or choroid (Ueno et al. 2008), supporting the use of VEGF antagonists in the treatment of retinal diseases. Two other studies focusing on subretinally injected AAV.sFlt-1 showed that this gene therapy approach is safe and effective for the long-term ( $8 \mathrm{mo}$ ) inhibition of pathological blood vessel growth in the eye (Lai et al. 2005, 2009).

To decrease potential long-term complications of anti-VEGF therapies, inducible, helper-dependent Ad vectors expressing sFlt-1 vectors (delivered intravitreally) have been tested for their therapeutic efficacy in a rat model of oxygen-induced retinopathy in a constitutive or doxycycline-inducible manner (Lamartina et al. 2007). The sFlt- 1 cDNA used in these studies had a similar structure to the sFlt- 1 form used by Rakoczy's group (Lai et al. 2005) that encodes the alternatively spliced, soluble sFlt-1 isoform. Treatment with these vectors resulted in detectable levels of sFlt-1, and retinal neovascularization was significantly inhibited. The therapeutic efficacy of the inducible, helper-dependent Ad vector was strictly doxycycline-dependent. The strategy of using an inducible vector may turn out to be a useful system for regulating protein expression in the eye.

To avoid the complications of immune responses to viral vectors, there are ongoing investigations into an alternate method involving direct injections into the ciliary muscle of a nonviral gene transfer vector expressing one of three different rat sFlt-1 variants: small-sFlt-1 (3 domains), medium-sFlt-1 (4 domains), and large sFlt- 1 ( 6 domains). All three sflt-1 variants significantly diminished vascular leakage and neovascularization in a rat model of laser-induced CNV (El Sanharawi et al. 2013). It is not clear at this point how long expression lasts with nonviral vectors compared with AAV vectors, which have shown ocular expression for several years.
Another approach under investigation is posttranscriptional silencing of VEGF gene expression using RNA interference (RNAi). Short interfering RNA (siRNA) designed against VEGF mRNA was shown to silence VEGF gene expression and inhibit the development of laserinduced $\mathrm{CNV}$ in the mouse eye (Reich et al. 2003). In another experiment by the same group, it was shown that intravitreal injection of siRNA against VEGF mRNA inhibited the growth and vascular permeability of laser-induced $\mathrm{CNV}$ in a nonhuman primate. This effect was dose-dependent and did not cause any change in electroretinogram, hemorrhage, inflammation, or clinical signs of toxicity (Tolentino et al. 2004). Gene therapy using this approach uses short hairpin RNA (shRNA) delivered by a plasmid or viral vector. The shRNA silences the target gene through a complex process resulting in the cleavage of the target mRNA (Macrae et al. 2006). An AAV8 vector expressing an anti-VEGF shRNA, when injected subretinally, significantly reduced CNV (up to $48 \%$ ) in a laser-induced murine model (Askou et al. 2012).

\section{Pigment Epithelium-Derived Factor (PEDF)}

PEDF is a $50 \mathrm{kDa}$ glycoprotein belonging to the serine proteinase inhibitor (SERPIN) superfamily (Tombran-Tink et al. 1991; Becerra et al. 1995). PEDF has neuronal differentiating activities (Tombran-Tink et al. 1991) and neurotrophic activities (Steele et al. 1993) and is a potent antiangiogenic factor (Stellmach et al. 2001). The ratio between VEGF and PEDF levels is altered in the aqueous and vitreous fluids from patients with diabetic retinopathy and AMD (Ogata et al. 2001; Ohno-Matsui et al. 2001).

Three different models of ocular neovascularization have been used to investigate the efficacy of PEDF gene transfer in inhibition of neovascularization (Mori et al. 2001a). In VEGFoverexpressing transgenic mice and in the oxygen-induced retinopathy mouse model, intravitreal injection of Ad-PEDF vector resulted in significant inhibition of neovascularization as compared with null vector (Mori et al. 2001a). Both intravitreal and subretinal injection of an 
P. Pechan et al.

Ad-PEDF vector significantly reduced CNV area in a mouse model of laser-induced CNV (Mori et al. 2001a) and even caused regression of already-established ocular neovascularization (Mori et al. 2002).

A safety study for intravitreal administration of Ad-PEDF was conducted in cynomolgus monkeys and resulted in dose-dependent, druginduced ocular toxicity. No toxicity was detected in the eye at a low dose of $1 \times 10^{8}$ particle units ( pu) Ad-PEDF, but dose-related inflammatory responses occurred at doses of $1 \times 10^{9}$ pu and higher (Rasmussen et al. 2003). Moreover, a significant decrease in electroretinographic response occurred at doses of $1 \times 10^{10} \mathrm{pu}$ or higher, correlating with more pronounced toxicity.

Periocular and intravitreal injections of E1/E4-deleted Ad vector expressing human PEDF (AdPEDF.11) was tested in a CNV model in pigs, which have eyes that are very similar to humans in size and scleral thickness. The periocular injection of $1 \times 10^{10}$ or $1 \times 10^{11} \mathrm{pu}$ of Ad-PEDF gave rise to increased levels of PEDF in the periocular tissue and choroid and significantly reduced $(77 \%)$ the amount of $\mathrm{CNV}$ at rupture sites in Bruch's membrane (Saishin et al. 2005). At a dose of $1 \times 10^{9} \mathrm{pu}$ injected intravitreally the reduction in CNV area was less pronounced (38\%). Periocular injections could be less invasive and potentially safer for patients.

A phase 1 clinical study (NCT00109499; GenVec) was completed in which 28 patients with advanced neovascular AMD were given a single intravitreal injection of an AdPEDF.11 in doses ranging from $10^{6}$ to $10^{9.5} \mathrm{pu}$ (Campochiaro et al. 2006). Six patients experienced increased intraocular pressure that was easily controlled by topical medication. Signs of mild, transient intraocular inflammation occurred in $25 \%$ of patients, but there was no severe inflammation, no serious adverse events, or dose-limiting toxicities. There were hints of antiangiogenic activity of PEDF in the high dose patients for a few months (Campochiaro et al. 2006), and this approach may be worth investigating further with vectors that provide longterm expression of PEDF.

\section{Endostatin and Angiostatin}

Endostatin, a cleavage product of collagen XVIII, participates in physiological regression of the hyaloid vasculature and regulation of retinal vascular development and is known to inhibit tumor angiogenesis. A role for endogenous endostatin in inhibiting experimental $\mathrm{CNV}$ has also been shown (Marneros et al. 2007). Intravenous (tail vein) injection of Adendostatin under control of the CMV or Rous sarcoma virus promoter also completely prevented $\mathrm{CNV}$ development in a laser-induced mouse model of CNV (Mori et al. 2001b). Two different vectors for subretinal endostatin delivery were tested in the double transgenic mouse model with doxycycline-induced expression of VEGF in the retina. Both the bovine immunodeficiency lentiviral vector and the helper-dependent Ad vector with tamoxifen-inducible expression of endostatin resulted in significant suppression of leakage of intravascular $\left[{ }^{3} \mathrm{H}\right]$ mannitol into the retina in this model (Takahashi et al. 2003). An equine infectious anemia virus (EIAV)-based vector encoding endostatin was evaluated in $\mathrm{C} 57 \mathrm{Bl} / 6 \mathrm{~J}$ mice with experimental laser-induced CNV (Balaggan et al. 2006). The vector effectively controlled angiogenesis and hyperpermeability without long-term deleterious effects, and significantly augmented the frequency of apoptosis within the induced $\mathrm{CNV}$ as compared with injected controls (Balaggan et al. 2006).

Angiostatin is a fragment of plasminogen that inhibits endothelial proliferation in vitro and tumor growth in vivo. Subretinal injection of AAV-angiostatin has been shown to significantly reduce the size of $\mathrm{CNV}$ lesions in a rat model of laser-induced CNV (Lai et al. 2001). Intravitreal injections of HIV-based lentiviral vector encoding angiostatin have shown that gene delivery of angiostatin can inhibit retinal neovascularization in a mouse oxygen-induced retinopathy model (Igarashi et al. 2003). EIAVbased vectors encoding angiostatin or endostatin have been evaluated in an experimental laser-induced CNV mouse model (Balaggan et al. 2006). Both vectors effectively controlled angiogenesis and hyperpermeability without long- 
Gene Therapies for Neovascular AMD

term deleterious effects; however, only the endostatin vector significantly augmented the frequency of apoptosis within the induced CNV as compared with injected controls (Balaggan et al. 2006).

The large capacity of lentiviral vectors such as EIAV enabled investigators to express both endostatin and angiostatin from a single EIAVbased vector. Subretinal injection of EIAV vectors expressing murine endostatin alone or in combination with angiostatin driven either by the CMV promoter or vitelliform macular dystrophy gene promoter caused significant suppression of $\mathrm{CNV}$ at laser-induced rupture sites in Bruch's membrane (Kachi et al. 2009).

Biodistribution analysis following subretinal administration of this dual vector (RetinoStat, Oxford BioMedica) into rhesus macaques and Dutch belted rabbits showed that the vector was localized within the ocular compartment, tolerated well, and capable of persistent expression (Binley et al. 2012). Following subretinal injection, endostatin and angiostatin protein levels peaked in the vitreous of rabbits at $1 \mathrm{mo}$, and the expression levels persisted for the 6-mo duration of the study. Mild to moderate ocular inflammation was seen, but it resolved by 1 mo postinjection in both species. There were no significant changes in electroretinogram or intraocular pressure in the treated eye compared with the control eye.

A phase I dose-escalation trial in patients with advanced neovascular AMD, the Gene Transfer of Endostatin/angiostatin for Macular Degeneration Trial (GEM Study, NCT01301 443), has been initiated to test the safety and bioactivity of subretinal injection of EIAV.CMVendostatin.angiostatin (RetinoStat). The study is testing safety and bioactivity of three dose levels of RetinoStat, with three subjects in each cohort and up to nine additional subjects dosed at the maximal tolerated dose. Bioactivity will be assessed by measuring changes from baseline in subretinal and intraretinal fluid by optical coherence tomography and by measuring the size of subretinal neovascular lesions by fluorescein angiography. Transgene expression will be assessed by measuring endostatin and angiostatin protein levels in aqueous samples at 3-mo intervals.

\section{CONCLUDING REMARKS}

Studies in animal models suggest that expression of antiangiogenic proteins in the eye by gene delivery could potentially benefit patients with neovascular AMD and avoid the need for repeated intraocular injections. Four different phase I/II clinical trials are in various stages of completion. Two of the trials (Ad-PEDF from GenVec and AAV2-sFLT01 from Genzyme) involve an intravitreal injection, which is currently the well-accepted method used to deliver Lucentis and Eylea in the clinic. The other two trials (EIAV-endostatin.angiostatin from Oxford BioMedica and AAV2-sflt-1 from Avalanche) involve subretinal injections in an operating room procedure. However, subretinal delivery can theoretically deliver higher levels of the therapeutic protein to the outer retina and choroid. Although these trials are not masked and are primarily safety trials, we should be able to generate some very useful data on the feasibility/ safety of ocular gene delivery, protein expression levels, and biological activity of the protein as measured by retina optical coherence tomography and fluorescence angiography within the next couple of years. This could potentially set the stage for the design of larger phase III clinical trials.

\section{REFERENCES}

Aiello LP, Pierce EA, Foley ED, Takagi H, Chen H, Riddle L, Ferrara N, King GL, Smith LE. 1995. Suppression of retinal neovascularization in vivo by inhibition of vascular endothelial growth factor (VEGF) using soluble VEGFreceptor chimeric proteins. Proc Natl Acad Sci 92: $10457-$ 10461.

Askou AL, Pournaras JAC, Pihlmann M, Svalgaard JD, Arsenijevic Y, Kostic C, Bek T, Dagnaes-Hansen F, Mikkelsen JG, Jensen TG, et al. 2012. Reduction of choroidal neovascularization in mice by adeno-associated virusdelivered anti-vascular endothelial growth factor short hairpin RNA. J Gene Med 14: 632-641.

Bainbridge JW, Mistry A, De Alwis M, Paleolog E, Baker A, Thrasher AJ, Ali RR. 2002. Inhibition of retinal neovascularisation by gene transfer of soluble VEGF receptor sFlt-1. Gene Ther 9: 320-326.

Balaggan KS, Binley K, Esapa M, MacLaren RE, Iqball S, Duran Y, Pearson RA, Kan O, Barker SE, Smith AJ, et al. 2006. EIAV vector-mediated delivery of endostatin or angiostatin inhibits angiogenesis and vascular hyperpermeability in experimental CNV. Gene Ther 13: $1153-$ 1165. 
P. Pechan et al.

Becerra SP, Sagasti A, Spinella P, Notario V. 1995. Pigment epithelium derived factor behaves like a noninhibitory serpin: Neurotrophic activity does not require the serpin reactive loop. J Biol Chem 270: 25992-25999.

Binley K, Widdowson PS, Kelleher M, de Belin J, Loader J, Ferrige G, Carlucci M, Esapa M, Chipchase D, AngellManning D, et al. 2012. Safety and biodistribution of an equine infectious anemia virus-based gene therapy, RetinoStat $(\circledR)$, for age-related macular degeneration. Hum Gene Ther 23: 980-991.

Boyer DS, Ophthotech Anti-PDGF in AMD Study Group. 2009. Combined inhibition of platelet-derived (PDGF) and vascular endothelial (VEGF) growth factors for the treatment of neovascular age-related macular degeneration (NV-AMD). Results of a phase 1 study. Invest Ophthatmol Vis Sci 50: E-Abstract 1260.

Brown DM, Kaiser PK, Michels M, Soubrane G, Heier JS, Kim RY, Judy P Sy, Schneider S, ANCHOR Study Group. 2006. Ranibizumab versus verteporfin for neovascular age-related macular degeneration. $N$ Engl J Med 355: 1432-1444.

Campa C, Kasman I, Ye W, Lee WP, Fuh G, Ferrara N. 2008. Effects of an anti-VEGF-A monoclonal antibody on laser-induced choroidal neovascularization in mice: Optimizing methods to quantify vascular changes. Invest Ophthalmol Vis Sci 49: 1178-1183.

Campochiaro PA, Nguyen QD, Shah SM, Klein ML, Holz E, Frank RN, Saperstein DA, Gupta A, Stout JT, Macko J, et al. 2006. Adenoviral vector-delivered pigment epithelium-derived factor for neovascular age-related macular degeneration: Results of a phase I clinical trial. Hum Gene Ther 17: 167-176.

Connolly DT, Heuvelman DM, Nelson R, Olander JV, Eppley BL, Delfino JJ, Siegel NR, Leimgruber RM, Feder J. 1989. Tumor vascular permeability factor stimulates endothelial cell growth and angiogenesis. J Clin Invest 84: $1470-1478$.

El Sanharawi M, Touchard E, Benard R, Bigey P, Escriou V, Mehanna C, Naud MC, Berdugo M, Jeanny JC, BeharCohen F. 2013. Long-term efficacy of ciliary muscle gene transfer of three sFlt-1 variants in a rat model of laserinduced choroidal neovascularization. Gene Ther 20: 1093-1103.

Ferrara N, Henzel WJ. 1989. Pituitary follicular cells secrete a novel heparin-binding growth factor specific for vascular endothelial cells. Biochem Biophys Res Commun 161: 851-859.

Ferrara N, Gerber HP. 2001. The role of vascular endothelial growth factor in angiogenesis. Acta Haematol 106: 148156.

Ferrara N, Chen H, Davis-Smyth T, Gerber HP, Nguyen TN, Peers D, Chisholm V, Hillan KJ, Schwall RH. 1998. Vascular endothelial growth factor is essential for corpus luteum angiogenesis. Nat Med 4: 336-340.

Gragoudas ES, Adamis AP, Cunningham ET, Feinsod M, Guyer DR. 2004. Pegaptanib for neovascular age-related macular degeneration. $N$ Engl J Med 351: 2805-2816.

Heier JS, Brown DM, Chong V, Korobelnik JF, Kaiser PK, Nguyen QD, Kirchhof B, Ho A, Ogura Y, Yancopoulos GD, et al. 2012. Intravitreal aflibercept (VEGF trap-eye) in wet age-related macular degeneration. Ophthalmol 119: $2537-2548$.
Holash J, Davis S, Papadopoulos N, Croll SD, Ho L, Russell M, Boland P, Leidich R, Hylton D, Burova E, et al. 2002. VEGF-Trap: A VEGF blocker with potent antitumor effects. Proc Natl Acad Sci 99: 11393-11398.

Honda M, Sakamoto T, Ishibashi T, Inomata H, Ueno H. 2000. Experimental subretinal neovascularization is inhibited by adenovirus-mediated soluble VEGF/flt-1 receptor gene transfection: A role of VEGF and possible treatment for SRN in age-related macular degeneration. Gene Ther 7: 978-985.

Igarashi T, Miyake K, Kato K, Watanabe A, Ishizaki M, Ohara K, Shimada T. 2003. Lentivirus-mediated expression of angiostatin efficiently inhibits neovascularization in a murine proliferative retinopathy model. Gene Ther 10: 219-226.

Julien S, Kreppel F, Beck S, Heiduschka P, Brito V, Schnichels S, Kochanek S, Schraermeyer U. 2008. A reproducible and quantifiable model of choroidal neovascularization induced by VEGF A165 after subretinal adenoviral gene transfer in the rabbit. Mol Vis 14: 1358-1372.

Kachi S, Binley K, Yokoi K, Umeda N, Akiyama H, Muramatu D, Iqball S, Kan O, Naylor S, Campochiaro PA. 2009. Equine infectious anemia viral vector-mediated codelivery of endostatin and angiostatin driven by retinal pigmented epithelium-specific VMD2 promoter inhibits choroidal neovascularization. Hum Gene Ther 20:31-39.

Kendall RL, Thomas KA. 1993. Inhibition of vascular endothelial cell growth factor activity by an endogenously encoded soluble receptor. Proc Natl Acad Sci 90: 10705-10709.

Klein R, Klein BE, Linton KL. 1992. Prevalence of agerelated maculopathy. The Beaver Dam Eye Study. Ophthalmol 99: 933-943.

Krzystolik MG, Afshari MA, Adamis AP, Gaudreault J, Gragoudas ES, Michaud NA, Li Wenjun, Connolly E, O'Neill CA, Miller JW. 2002. Prevention of experimental choroidal neovascularization with intravitreal antivascular endothelial growth factor antibody fragment. Arch Ophthalmol 120: 338-346.

Kwak N, Okamoto N, Wood JM, Campochiaro PA. 2000. VEGF is major stimulator in model of choroidal neovascularization. Invest Ophthalmol Vis Sci 41: 31583164.

Lai CC, Wu WC, Chen SL, Xiao X, Tsai TC, Huan SJ, Chen TL, Tsai RJ, Tsao YP. 2001. Suppression of choroidal neovascularization by adeno-associated virus vector expressing angiostatin. Invest Ophthalmol Vis Sci 42: 2401-2407.

Lai YK, Shen WY, Brankov M, Lai CM, Constable IJ, Rakoczy PE. 2002. Potential long-term inhibition of ocular neovascularisation by recombinant adeno-associated virusmediated secretion gene therapy. Gene Ther 9: 804-813.

Lai CM, Shen WY, Brankov M, Lai YK, Barnett NL, Lee SY, Yeo IYS, Mathur R, Ho JES, Pineda P, et al. 2005. Longterm evaluation of AAV-mediated sFlt-1 gene therapy for ocular neovascularization in mice and monkeys. $\mathrm{Mol}$ Ther 12: 659-668.

Lai CM, Estcourt MJ, Wikstrom M, Himbeck RP, Barnett NL, Brankov M, Tee LBG, Dunlop SA, Degli-Esposti MA, Rakoczy EP. 2009. rAAV.sFlt-1 gene therapy achieves lasting reversal of retinal neovascularization in the absence of a strong immune response to the viral vector. Invest Ophthalmol Vis Sci 50: 4279-4287. 
Gene Therapies for Neovascular AMD

Lai CM, Estcourt MJ, Himbeck RP, Lee SY, Yeo IYS, Luu C, Loh BK, Lee MW, Barathi A, Villano J, et al. 2012. Preclinical safety evaluation of subretinal AAV2.sFlt-1 in non-human primates. Gene Ther 19: 999-1009.

Lamartina S, Cimino M, Roscilli G, Dammassa E, Lazzaro D, Rota R, Ciliberto G, Toniatti C. 2007. Helper-dependent adenovirus for the gene therapy of proliferative retinopathies: Stable gene transfer, regulated gene expression and therapeutic efficacy. J Gene Med 9: 862-874.

Lebherz C, Auricchio A, Maguire AM, Rivera VM, Tang W, Grant RL, Clackson T, Bennett J, Wilson JM. 2005. Nonhuman primate models for diabetic ocular neovascularization using AAV2-mediated overexpression of vascular endothelial growth factor. Diabetes 54: 1141-1149.

Lukason M, DuFresne E, Rubin H, Pechan P, Li Q, Kim I, Kiss S, Flaxel C, Collins M, Miller J, et al. 2011. Inhibition of choroidal neovascularization in a nonhuman primate model by intravitreal administration of an AAV2 vector expressing a novel anti-VEGF molecule. Mol Ther 19: 260-265.

MacLachlan TK, Lukason M, Collins M, Munger R, Isenberger E, Rogers C, Malatos S, DuFresne E, Morris J, Calcedo R, et al. 2011. Preclinical safety evaluation of AAV2-sFLT01-A gene therapy for age-related macular degeneration. Mol Ther 19: 326-334.

Macrae IJ, Zhou K, Li F, Repic A, Brooks AN, Cande WZ, Adams PD, Doudna JA. 2006. Structural basis for doublestranded RNA processing by Dicer. Science 311: 195-198.

Marneros AG, She H, Zambarakji H, Hashizume H, Connolly EJ, Kim I, Gragoudas ES, Miller JW, Olsen BR. 2007. Endogenous endostatin inhibits choroidal neovascularization. FASEB J 21: 3809-3818.

Miller JW, Schmidt-Erfurth U, Sickenberg M, Pournaras CJ, Laqua H. 1999. Photodynamic therapy with verteporfin for choroidal neovascularization caused by age-related macular degeneration: Results of a single treatment in a phase 1 and 2 study. Arch Ophthamol 117: 1161-1173.

Mori K, Duh E, Gehlbach P, Ando A, Takahashi K, Pearlman J, Mori K, Yang HS, Zack DJ, Ettyreddy D, et al. 2001a. Pigment epithelium-derived factor inhibits retinal and choroidal neovascularization. J Cell Physiol 188: 253-263.

Mori K, Ando A, Gehlbach P, Nesbitt D, Takahashi K, Goldsteen D, Penn M, Chen CT, Mori K, Melia M, et al. 2001b. Inhibition of choroidal neovascularization by intravenous injection of adenoviral vectors expressing secretable endostatin. Am J Pathol 159: 313-320.

Mori K, Gehlbach P, Ando A, McVey D, Wei L, Campochiaro PA. 2002. Regression of ocular neovascularization in response to increased expression of pigment epitheliumderived factor. Invest Ophthalmol Vis Sci 43: 2428-2434.

Ogata N, Tombran-Tink J, Nishikawa M, Nishimura T, Mitsuma Y, Sakamoto T, Matsumura M. 2001. Pigmentepithelium derived factor in the vitreous is low in diabetic retinopathy and high in rhegmatogenous detachment. Am J Ophthalmol 132: 378-382.

Ohno-Matsui K, Morita I, Tombran-Tink J, Mrazek D, Onodera M, Uetama T, Hayano M, Murota SI, Mochizuki M. 2001. Novel mechanism for age-related macular degeneration: An equilibrium shift between the angiogenesis factors VEGF and PEDF. J Cell Physiol 189: 323-333.
Ozaki H, Seo MS, Ozaki K, Yamada H, Yamada E, Hofmann F, Wood J, Campochiaro PA. 2000. Blockade of vascular endothelial cell growth factor receptor signaling is sufficient to completely prevent retinal neovascularization. Am J Pathol 156: 679-707.

Pechan P, Rubin H, Lukason M, Ardinger J, DuFresne E, Hauswirth WW, Wadsworth SC, Scaria A. 2009. Novel anti-VEGF chimeric molecules delivered by AAV vectors for inhibition of retinal neovascularization. Gene Ther 16: $10-16$.

Presta LG, Chen H, O'Connor SJ, Chisholm V, Meng YG, Krummen L, Winkler M, Ferrara N. 1997. Humanization of an anti-vascular endothelial growth factor monoclonal antibody for the therapy of solid tumors and other disorders. Cancer Res 57: 4593-4599.

Rakoczy PE, Brankov M, Fonceca A, Zaknich T, Rae BC, Lai CM. 2003. Enhanced recombinant adeno-associated virus-mediated vascular endothelial growth factor expression in the adult mouse retina: A potential model for diabetic retinopathy. Diabetes 52: 857-863.

Rasmussen HS, Smith AC, Durham RJ, Rasmussen CS, Bee WH, Wills MC, Munger RJ, Tomlinson MJ, MacGill R, King CR. 2003. Safety of intravitreal adenoviral gene therapy containing human pigment epithelium-derived factor transgene in monkeys. Preclinica 1: 77-85.

Reich SJ, Fosnot J, Kuroki A, Tang W, Yang X, Maguire AM, Bennett J, Tolentino MJ. 2003. Small interfering RNA (siRNA) targeting VEGF effectively inhibits ocular neovascularization in a mouse model. Mol Vis 9: 210-216.

Rosenfeld PJ, Brown DM, Heier JS, Boyer DS, Kaiser PK, Chung CY, Kim RY, MARINA Study Group. 2006. Ranibizumab for neovascular age-related macular degeneration. N Eng J Med 355: 1419-1431.

Rota R, Riccioni T, Zaccarini M, Lamartina S, Del Gallo A, Fusco A, Kovesdi I, Balestrazzi E, Abeni DC, Ali RR, et al. 2004. Marked inhibition of retinal neovascularization in rats following soluble-flt-1 gene transfer. J Gene Med 6: 992-1002.

Ryan SJ. 1979. The development of an experimental model of subretinal neovascularization in disciform macular degeneration. Trans Am Ophthalmol Soc 77: 707-745.

Saint-Geniez M, Maharaj ASR, Walshe TE, Tucker BA, Sekiyama E, Kurihara T, Darland DC, Young MJ, D’Amore PA. 2008. Endogenous VEGF is required for visual function: Evidence for a survival role on muller cells and photoreceptors. PLoS ONE 3: e3554.

Saint-Geniez M, Kurihara T, Sekiyama E, Maldonado AE, D'Amore PA. 2009. An essential role for RPE-derived soluble VEGF in maintenance of the choriocapillaries. Proc Natl Acad Sci 106: 18751-18756.

Saishin Y, Saishin Y, Takahashi K, Silva RL, Hylton D, Rudge JS, Wiegand SJ, Campochiaro PA. 2003. VEGFTRAP(R1R2) suppresses choroidal neovascularization and VEGF-induced breakdown of the blood-retinal barrier. J Cell Physiol 195: 241-248.

Saishin Y, Silva RL, Saishin Y, Kachi S, Aslam S, Gong YY, Lai H, Carrion M, Harris B, Hamilton M, et al. 2005. Periocular gene transfer of pigment epithelium-derived factor inhibits choroidal neovascularization in a humansized eye. Hum Gene Ther 16: 473-478.

Shibuya M, Yamaguchi S, Yamane A, Ikeda T, Tojo A, Matsushime H, Sato M. 1990. Nucleotide sequence and 
P. Pechan et al.

expression of a novel human receptor-type tyrosine kinase gene $(f l t)$ closely related to the fms family. Oncogene 5: 519-524.

Steele FR, Chader GJ, Johnson LV, Tombran-Tink J. 1993 Pigment epithelium-derived factor: Neurotrophic activity and identification as a member of the serine protease inhibitor gene family. Proc Natl Acad Sci 90: 1526-1530.

Stellmach V, Crawford SE, Zhou W, Bouck N. 2001. Prevention of ischemia-induced retinopathy by the natural ocular antiangiogenic agent pigment epithelium-derived factor. Proc Natl Acad Sci 98: 2593-2597.

Takahashi K, Saishin Y, Saishin Y, Lima SR, Oshima Y, Oshima S, Melia M, Paszkiet B, Zerby D, Kadan MJ, et al. 2003. Intraocular expression of endostatin reduces VEGF-induced retinal vascular permeability, neovascularization, and retinal detachment. FASEB J 17: 896-898.

Tolentino MJ, Brucker AJ, Fosnot J, Ying GS, Wu IH, Malik G, Wan S, Reich SJ. 2004. Intravitreal injection of vascular endothelial growth factor small interfering RNA inhibits growth and leakage in a nonhuman primate, laser-induced model of choroidal neovascularization. Retina 24: $132-138$.

Tombran-Tink J, Chader GC, Johnson LV. 1991. PEDF: A pigment epithelium-derived factor with potent neuronal differentiative activity. Exp Eye Res 53: 411-414.
Tuo J, Bojanowski CM, Zhou M, Shen D, Ross RJ, Rosenberg KI, Cameron DJ, Yin C, Kowalak JA, Zhuang Z, et al. 2007. Murine $\mathrm{Ccl} 2 / \mathrm{Cx} 3 \mathrm{cr} 1$ deficiency results in retinal lesions mimicking human age-related macular degeneration. Invest Ophthalmol Vis Sci 48: 3827-3836.

Tuo J, Pang JJ, Cao X, Shen D, Zhang J, Scaria A, Wadsworth SC, Pechan P, Boye SL, Hauswirth WW, et al. 2012. AAV5mediated sFLT01 gene therapy arrests retinal lesions in $\mathrm{Ccl}^{-/-} / \mathrm{Cx3}_{\mathrm{crl}} \mathrm{I}^{-/}$mice. Neurobiol Aging 33: 433.e1-10.

Ueno S, Pease ME, Wersinger DMB, Masuda T, Vinores SA, Licht T, Zack DJ, Quigley H, Keshet E, Campochiaro PA. 2008. Prolonged blockade of VEGF family members does not cause identifiable damage to retinal neurons or vessels. J Cell Physiol 217: 13-22.

Yi X, Ogata N, Komada M, Yamamoto C, Takahashi K, Omori K, Uyama M. 1997. Vascular endothelial growth factor expression in choroidal neovascularization in rats. Graefes Arch Clin Exp Ophthalmol 235: 313-319.

Yu MJ, Shen WY, Lai MC, Constable IJ, Rakoczy PE. 1999. Generation and characterization of a recombinant adenovirus expressing vascular endothelial growth factor for studies of neovascularization in the eye. Aust $N Z J$ Ophthalmol 27: 250-253. 


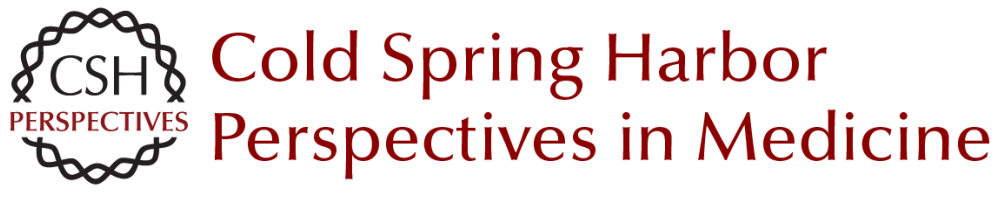

\section{Gene Therapies for Neovascular Age-Related Macular Degeneration}

Peter Pechan, Samuel Wadsworth and Abraham Scaria

Cold Spring Harb Perspect Med 2015; doi: 10.1101/cshperspect.a017335 originally published online December 18, 2014

\section{Subject Collection Retinal Disorders: Genetic Approaches to Diagnosis and Treatment}

Trial by "Firsts": Clinical Trial Design and Regulatory Considerations in the Development and Approval of the First AAV Gene Therapy Product in the United States

Kathleen Z. Reape and Katherine A. High

Immunology of Retinitis Pigmentosa and Gene Therapy-Associated Uveitis

Paul Yang, Debarshi Mustafi and Kathryn L. Pepple

Developing New Vectors for Retinal Gene Therapy Emilia A. Zin, Bilge E. Ozturk, Deniz Dalkara, et al.

Beyond the NEI-VFQ: Recent Experience in the Development and Utilization of Patient-Reported Outcomes for Inherited Retinal Diseases

Todd Durham, Judit Banhazi, Francesco Patalano, et al.

Electronic Retinal Prostheses

Daniel Palanker

Alternative RNA Splicing in the Retina: Insights and Perspectives

Casey J. Keuthan, Sadik Karma and Donald J. Zack

X-Linked Retinoschisis

Cristy A. Ku, Lisa W. Wei and Paul A. Sieving

A Systematic Review of Optogenetic Vision Restoration: History, Challenges, and New Inventions from Bench to Bedside

Antonia Stefanov and John G. Flannery
Lessons Learned from the Development of the

First FDA-Approved Gene Therapy Drug,

Voretigene Neparvovec-rzyl Jean Bennett and Albert M. Maguire

Therapeutic Gene Editing in Inherited Retinal Disorders Jinjie Ling, Laura A. Jenny, Ashley Zhou, et al.

Cell-Based Therapies: Strategies for Regeneration Marina Pavlou and Thomas A. Reh

The Importance of Natural History Studies in Inherited Retinal Diseases Allison Ayala, Janet Cheetham, Todd Durham, et al.

Photoreceptor Cell Replacement Using Pluripotent Stem Cells: Current Knowledge and Remaining Questions

Christelle Monville, Olivier Goureau and Karim Ben M'Barek

iPSC-RPE in Retinal Degeneration: Recent

Advancements and Future Perspectives

Tadao Maeda and Masayo Takahashi

Retinal Degeneration Animal Models in Bardet-

Biedl Syndrome and Related Ciliopathies Clarisse Delvallée and Hélène Dollfus

Mobility Testing and Other Performance-Based Assessments of Functional Vision in Patients with Inherited Retinal Disease

Daniel Chung, Colas Authié and Laure Blouin

For additional articles in this collection, see http://perspectivesinmedicine.cshlp.org/cgi/collection/ 
For additional articles in this collection, see http://perspectivesinmedicine.cshlp.org/cgi/collection/ 